\title{
Efektivitas Model Pembelajaran Blended Learning Terhadap Hasil Belajar Mahasiswa Di Masa Pandemi Covid 19
}

\author{
Nelliraharti $^{1^{*}}$, Murnia Suri ${ }^{2}$ \\ 1.2. Fakultas Keguruan dan Ilmu Pendidikan, Universitas Ubudiyah Indonesia. Jln Alue Naga Desa Tibang, \\ Kecamatan Syiah Kuala, Banda Aceh 23114, Indonesia \\ *raharti_nelly@uui.ac.id
}

\begin{abstract}
Blended Learning is a learning model that combines face-to-face learning (conventional) and online learning. The research method used is Pre-Experimental Designs with the One -Group Pretest- Posttest Design model, which aims to assess the differences in learning outcomes of the blended learning learning model with the direct face-to-face learning model (conventional). The study was conducted on students of the English Education Study Program at UIN Ar-raniry in the Even semester 2020/2021, totaling 30 people who were selected using a purposive sampling technique. Data was collected using test instruments, while data analysis techniques used prerequisite tests and hypothesis testing. Based on the research, the t-count value is 9.517 and at a significance level of 0.05, the t-table value is 2.045, which means $t$-count $>$ t-table $(2.221>2.021)$ then Ho is rejected and Ha is accepted, meaning that there is an average difference between the results of the Pretest and Posttest, which means that blended learning model provides significant effectiveness and is better than face-to-face (conventional) learning. However, based on the average value of the $N$-gain Score of 29.90 . or $29.90 \%$ included in the ineffective category. This is understandable due to various obstacles and limitations that cause learning cannot be carried out optimally. So it is natural that the effectiveness of the Blended learning learning model in this study is not effective for improving learning outcomes.
\end{abstract}

Keywords: effectiveness, learning model, blended learning, achievement

\begin{abstract}
Abstrak
Blended Learning merupakan salah satu model pembelajaran yang memadukan pembelajaran tatap muka (konvensional) dan pembelajaran online. Metode penelitian yang digunakan adalah Pre-Experimental Designs dengan model One -Group Pretest- Postest Design, yang bertujuan untuk menilai perbedaan hasil belajar model pembelajaran blended learning dengan model pembelajaran tatap muka langsung (konvensional). Penelitian dilakukan pada mahasiswa Prodi Pendidikan Bahasa Inggris UIN Ar-raniry di semester Genap 2020/2021 yang berjumlah 30 orang yang dipilih dengan teknik purposive sampling. Pengumpulan data dilakukan dengan menggunakan instrumen tes, sedangkan teknik analisis data menggunakan uji prasyarat dan uji hipotesis. Berdasarkan penelitian diperoleh nilai $\mathrm{t}$ hitung sebesar 9,517 dan pada taraf signifikansi 0,05 diperoleh nilai $\mathrm{t}$ tabel sebesar 2,045 yang artinya $t$ hitung $>t$ tabel $(9,517>2,045)$ maka Ho ditolak dan Ha diterima artinya terdapat perbedaan rata-rata antara hasil belajar Pretest dan Posttest yang berarti bahwa pembelajaran model blended learning memberikan efektivitas yang signifikan dan lebih baik dibandingkan dengan pembelajaran tatap muka (konvensional). Namun berdasarkan nilai rata-rata N-gain Score sebesar 29,90. atau 29,90\% termasuk dalam kategori tidak efektif. Hal ini cukup dimaklumi mengingat berbagai kendala dan keterbatasan yang menyebabkan pembelajaran belum dapat dilaksanakan secara maksimal. Sehingga wajar sekali efektivitas model pembelajaran Blended learning dalam penelitian ini tidak efektif untuk meningkatkan hasil belajar.
\end{abstract}

Kata kunci: efektivitas model pembelajaran, blended learning, hasil belajar

\section{Pendahuluan}

Kemajuan teknologi informasi dan komunikasi di era revolusi industri 4.0 telah memberikan pengaruh yang besar terhadap dunia pendidikan khususnya dalam proses pembelajaran. Kemudahan akses internet telah digunakan oleh para pengajar dalam mencari berbagai referensi terkait metode, model dan materi pembelajaran untuk meningkatkan kualitas 
pendidikan. Teknologi informasi dapat diterima sebagai media dalam melaksanakan proses pendidikan termasuk membantu proses belajar mengajar yang juga melibatkan pencarian referensi dan sumber informasi [1].

Blended learning merupakan model pembelajaran yang memadukan pembelajaran tatap muka dan belajar online. Blended learning adalah model pembelajaran campuran yang dapat dilakukan secara tatap muka dan daring [2]. Blended learning merupakan kemudahan belajar yang memadukan berbagai cara penyampaian, model pengajaran, dan gaya belajar, memperkenalkan berbagai pilihan media dialog antara fasilitator dan orang yang diajar. Blended learning juga merupakan perpaduan antara pengajaran tatap muka dan pengajaran online., tetapi lebih dari itu sebagai unsur interaksi sosial. Blended learning merupakan gabungan dari dua model pembelajaran yang terpisah secara historis, yaitu sistem pembelajaran tatap muka (konvensional) dan sistem pembelajaran terdistribusi (online) dengan menekankan pada peran sentral teknologi informasi dan komunikasi berbasis komputer dalam model pembelajaran [3].

Musibah pandemi covid-19 yang dimulai sejak awal tahun 2020 telah memberikan dampak yang besar bagi dunia pendidikan mulai dari tingkat PAUD sampai pada Perguruan Tinggi. Kebijakan pemerintah yang mengalihkan pembelajaran dari tatap muka menjadi pembelajaran dalam jaringan (online), semua siswa dan guru harus melakukan proses belajar mengajar dari rumah masing-masing secara mendadak tanpa adanya persiapan sama sekali. Hal ini patut menimbulkan kendala yang besar dari ketidaksiapan berbagai unsur di dunia pendidikan. Bagaimanapun, perubahan proses belajar mengajar dari tatap muka menjadi daring atau online membutuhkan kesiapan dari semua unsur, mulai dari pemerintah, sekolah, guru, siswa dan orang tua.

Pembelajaran daring tidak sepenuhnya berjalan efektif, tantangan dan kendala pembelajaran daring sangat dirasakan oleh masyarakat yang berada di daerah terpencil, diantaranya keterbatasan penguasaan teknologi informasi oleh guru dan siswa dimana kondisi guru di Indonersia tidak semuanya paham penggunaan teknologi dan begitu juga dengan siswa. Sarana dan prasarana yang kurang memadai, akses internet yang terbatas dimana jaringan internet benar-benar belum merata ke seluruh pelosok negeri, keterbatasan biaya walaupun pemerintah sedikit telah membantu kouta internet gratis bagi guru dan siswa, kerugian siswa pada penilaian, adanya bentuk penugasan di hampir setiap pertemuan justru dianggap menjadi beban bagi siswa dan orang tua terutama di tingkat Sekolah Dasar dimana para orang tua pun turut andil dalam pembelajaran daring menjalankan sebagian peran guru dan lain sebagainya. Kondisi pandemi akhirnya memaksa para pemangku kebijakan di bidang pendidikan untuk dapat menyesuaikan diri dalam melaksanakan proses pembelajaran.

Setelah terlaksananya pembelajaran daring lebih dari satu semester dan melihat situasi dan kondisi serta evaluasi selama pembelajaran daring, akhirnya pemerintah mengumumkan Surat Keputusan Bersama (SKB) tentang panduan penyelenggaran pembelajaran semester genap 2020/2021. Melalui SKB tersebut, pemerintah melakukan penyesuaian kebijakan untuk memberikan izin kepada pemerintah daerah / kanwil/ kantor kemenag dan tetap dilanjutkan dengan izin berjenjang dari satuan pendidikan dan orang tua melalui komite sekolah untuk pembelajaran tatap muka di semester genap 2020/2021 yang dimulai awal Januari 2021. Keputusan tersebut dilatarbelakangi oleh berbagai pertimbangan dampak yang dapat terjadi kepada siswa apabila pembelajaran jarak jauh/PJJ dilaksanakan lebih lama (Dilansir dari paparan Kemendikbud tanggal 20 November 2020)

Meskipun Pelaksanaan pembelajaran tatap muka pada semester Genap 2020/2021 masih dilematis. Namun kota Banda Aceh khususnya dibawah jajaran kemenag memberikan izin untuk pembelajaran tatap muka dengan tetap mengedepankan protokol kesehatan. Namun demikian Fakultas Tarbiyah dan Keguruan UIN Ar-raniry merupakan salah satu Perguruan Tinggi yang menerapkan model pembelajaran tatap muka dan daring yang dikenal dengan blended learning di semester genap 2020/2021.

Selain itu, perlu adanya keefektifan terhadap pelaksanaan pembelajaran tidak hanya berkaitan 
dengan teknis dan fasilitas internet saja. Keefektivitas pembelajaran akan meningkatkan hasil belajar. Kemampuan siswa memahami konsep dan materi pembelajaran yang telah diberikan oleh pendidik akan menentukan hasil belajarnya. Seorang pendidik yang professional tentu akan melakukan inovasi dan kolaborasi metode maupun model pembelajaran yang cocok digunakan saat ini untuk meningkatkan keefektivitas pembelajaran. Oleh karena itu penulis tertarik untuk mengkaji lebih mendalam melalui sebuah penelitian dengan judul "Efektivitas Model Pembelajaran Blended Learning Terhadap Hasil Belajar Mahasiswa Pada Masa Pandemi Covid 19“.

\section{METODE PENELITIAN}

Penelitian ini termasuk jenis penelitian PreExperimental Designs dengan model One -Group Pretest- Postest Design, yaitu desain penelitian yang terdapat pretest sebelum diberi perlakuan dan postest setelah diberi perlakuan. Dengan demikian hasil perlakuannya dapat diketahui lebih akurat, karena dapat membandingkan dengan keadaan sebelum diberi perlakuan [4]. Desain penelitiannya dapat digambarkan sebagai berikut:

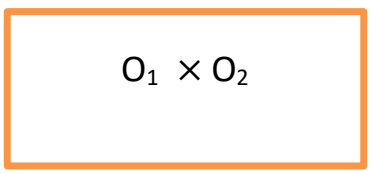

Keterangan : $\quad \mathrm{O}_{1}=$ nilai pretest

$$
\mathrm{O}_{2}=\text { nilai postest }
$$

Kegiatan penelitian ini bertujuan untuk menilai perbedaan hasil belajar model pembelajaran blended learning dengan model pembelajaran tatap muka langsung (konvensional). Hipotesis yang diajukan adalah model pembelajaran blended learning lebih efektif dari pada model konvensional, yang di ukur melalui nilai hasil belajar mahasiswa.

Penelitian dilakukan pada mahasiswa Prodi Pendidikan Bahasa Inggris Fakultas Tarbiyah dan Keguruan UIN Ar-raniry yang mengikuti mata kuliah Statistik Pendidikan di semester Genap 2020/2021 yang berjumlah 30 orang yang dipilih dengan teknik purposive sampling. Pengumpulan data dilakukan dengan menggunakan instrumen tes sedangkan teknik analisis data menggunakan uji prasyarat dan uji hipotesis. Uji prasyarat yaitu uji normalitas sedangkan uji hipotesis menggunakan uji beda rata-rata yaitu uji - $t$ dan uji Normalitas gain (N-gain).

\section{HASIL DAN PEMBAHASAN}

Pada awal semester pembelajaran dimulai secara tatap muka langsung sebanyak 4 kali pertemuan dan pada pertemuan ke lima diadakan quis. Nilai quis tersebut dijadikan sebagai nilai Pretest. Dikarenakan kasus covid-19 di Aceh yang mengalami peningkatan, akhirnya pada pertemuan keenam sampai seterusnya pembelajaran beralih ke model blended learning yaitu pembelajaran campuran tatap muka secara virtual melalui video conference via Zoom atau google meet dan belajar online melalui google Classroom, dimana pada pertemuan ke 9 diadakan Ujian Tengah Semester (UTS). Nilai dari UTS tersebut dijadikan sebagai Posstest dan hasilnya adalah seperti pada tabel berikut ini:

Tabel 1. Nilai Pretsest dan Posttest

\begin{tabular}{|c|c|c|}
\hline & Prestest & Posttest \\
\hline 1 & 60 & 65 \\
\hline 2 & 70 & 70 \\
\hline 3 & 70 & 90 \\
\hline 4 & 65 & 80 \\
\hline 5 & 85 & 95 \\
\hline 6 & 70 & 75 \\
\hline 7 & 50 & 60 \\
\hline 8 & 70 & 80 \\
\hline 9 & 60 & 70 \\
\hline 10 & 70 & 75 \\
\hline 11 & 60 & 75 \\
\hline 12 & 75 & 75 \\
\hline 13 & 60 & 75 \\
\hline 14 & 85 & 95 \\
\hline 15 & 70 & 90 \\
\hline 16 & 65 & 75 \\
\hline 17 & 75 & 80 \\
\hline 18 & 50 & 65 \\
\hline 19 & 65 & 70 \\
\hline 20 & 70 & 80 \\
\hline 21 & 65 & 85 \\
\hline 22 & 75 & 80 \\
\hline 23 & 60 & 70 \\
\hline 24 & 75 & 80 \\
\hline 25 & 70 & 80 \\
\hline 26 & 75 & 80 \\
\hline
\end{tabular}




\begin{tabular}{ccc}
\hline & Prestest & Posttest \\
\hline 27 & 75 & 80 \\
28 & 60 & 70 \\
29 & 70 & 75 \\
30 & 60 & 70 \\
\hline
\end{tabular}

\section{Uji Normalitas}

Uji normalitas merupakan salah satu uji persyaratan analisis sebelum dilakukan uji hipotesis. Jadi sebelum uji hipotesis dilakukan harus dipastikan terlebih dahulu bahwa datanya harus normal. Salah satu cara untuk mendeteksi kenormalan data adalah dengan uji Shapiro Wilk yang pada umumnya digunakan untuk sampel yang jumlahnya kecil (kurang dari 50) dengan menggunakan bantuan program SPSS. Dalam pengujian, suatu data dikatakan berdistribusi normal apabila nilai signifikansi lebih dari 0,05 (sig. > 0,05)

Tabel 2. Tests of Normality

\begin{tabular}{|l|c|c|c|c|c|c|}
\hline \multirow{2}{*}{} & \multicolumn{3}{|c|}{ Kolmogorov Smirnov } & \multicolumn{3}{c|}{ Shapiro-Wilk } \\
\cline { 2 - 7 } & Statistic & df & Sig. & Statistic & df & Sig. \\
\hline Pretest & .176 & 30 & .018 & .937 & 30 & .074 \\
Posttest & .193 & 30 & .006 & .942 & 30 & .102 \\
\hline
\end{tabular}

a. Lilliefors Significance Correction

Berdasarkan output di atas pada bagian Shapiro Wilk diketahui nilai Sig. untuk Pretest sebesar 0,074 dan untuk Posttest sebesar 0,102. Karena nilai tersebut lebih besar dari 0,05 maka dapat disimpulkan bahwa data nilai pretest dan posttest berdistribusi normal.

\section{Uji Hipotesis}

Pengujian hipotesis menggunakan uji Paired sampel t-test dengan menggunakan SPSS. Hipotesis dalam bentuk kalimat dapat dirumuskan sebagai berikut:

- Ho : tidak ada perbedaan rata-rata antara hasil belajar pretest dengan posttest yang artinya tidak ada pengaruh penggunaan model pembelajaran Blended Learnig untuk meningkatkan hasil belajar mahasiswa

- Ha : ada perbedaan rata-rata antara hasil belajar pretest dengan posttest yang artinya ada pengaruh penggunaan model pembelajaran Blended Learning untuk meningkatkan hasil belajar mahasiswa

Tabel 3. Paired Samples Statistics

\begin{tabular}{|cc|c|c|c|c|}
\hline & & Mean & N & $\begin{array}{c}\text { Std. } \\
\text { Deviation }\end{array}$ & $\begin{array}{c}\text { Std. Error } \\
\text { Mean }\end{array}$ \\
\hline \multirow{2}{*}{ Pair 1 } & Pretest & 67.67 & 30 & 8.380 & 1.530 \\
& Posttest & 77.00 & 30 & 8.367 & 1.528 \\
\hline
\end{tabular}

Dasar pengambilan keputusan dalam uji Paired sample t-test berdasarkan nilai signifikansi ( $\mathrm{sig}$ ) adalah sebagai berikut:

- Jika nilai Sig. (2-tailed) $<0,05$ maka Ho ditolak adan Ha diterima

- Jika nilai Sig. (2-tailed) > 0,05 maka Ho diterima dan Ha ditolak.

Output pada tabel 3 memperlihatkan ringkasan hasil statistik deskriptif dari kedua sampel yang diteliti yaitu pretest dan posttest. Untuk nilai pretest diperoleh rata-rata atau Mean sebesar 67,67 dan standar deviasi sebesar 8,380. Sementara untuk nilai posttest diperoleh nilai ratarata atau Mean sebesar 77 dan standar deviasi sebesar 8,367. Sampel yang digunakan berjumlah 30 orang. Karena rata-rata pretest lebih kecil dari posttest $(67,67<77)$ maka secara deskriptif ada perbedaan rata-rata hasil belajar prestest dan hasil belajar posttest. Selanjutnya untuk membuktikan apakah perbedaan tersebut signifikan atau tidak, dapat dilihat pada tabel di bawah ini

Tabel 4. Paired Samples Test

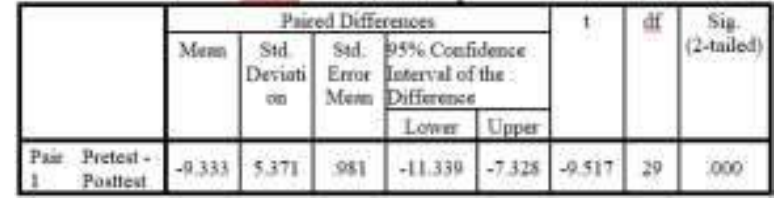

Berdasarkan tabel output di atas diketahui nilai Sig.(2-tailed) adalah sebesar 0,000 $<0,05$, maka Ho ditolak dan Ha diterima. Sehingga dapat disimpulkan bahwa ada perbedaan rata-rata antara hasil belajar Pretest dengan hasil belajar Posttest yang artinya ada pengaruh penggunaan model pembelajaran Blended Learning untuk meningkatkan hasil belajar mahasiswa

Pengujian hipotesis dalam uji paired sampel t-test dapat juga dengan membandingkan nilai $t$ hitung dengan $\mathrm{t}$ tabel. Dasar pengambilan keputusannya adalah;

- Jika nilai $\mathrm{t}_{\text {hitung }}>\mathrm{t}$ tabel maka Ho ditolak atau Ha diterima

- Jika nilai $\mathrm{t}_{\text {hitung }}<\mathrm{t}_{\text {tabel }}$ maka Ho diterima atau Ha ditolak

Berdasarkan output di atas diketahui nilai $t$ hitung sebesar 9,517. Untuk t tabel dengan $\mathrm{df}=29$ dan taraf signifikansi 0,05 diperoleh nilai $t_{\text {tabel }}$ sebesar 2,045. Dengan demikian $\mathrm{t}$ hitung $>\mathrm{t}$ tabel $(9,517>$ 2,045) maka Ho ditolak dan Ha diterima artinya terdapat perbedaan rata-rata antara hasil belajar Pretest dan Posttest. Kesimpulan ini mengandung arti bahwa pembelajaran model blended learning memberikan efektivitas yang signifikan dan lebih baik dibandingkan dengan pembelajaran tatap 
muka (konvensional) dalam meningkatkan hasil belajar mahasiswa.

Selanjutnya untuk mengetahui seberapa besar efektivitas penggunaan model blended learning digunakan uji $\mathrm{N}$ gain dengan cara menghitung selisih nilai pretest dan nilai posttest. Adapun rumus yang digunakann untuk menghitung $\mathrm{N}$-gain score adalah :

$$
N \text { Gain }=\frac{\text { Skor Posttest }- \text { Skor Pretest }}{\text { Skor Ideal }- \text { Skor Pretsest }}
$$

Adapun kategori perolehan nilai $\mathrm{N}$ gain score dapat dilihat pada tabel di bawah ini [7].

\begin{tabular}{cc} 
Tabel 5. Tafsiran Efektivitas N Gain \\
\hline Persentase & Tafsiran \\
\hline$<40$ & Tidak efektif \\
$40-55$ & Kurang efektif \\
$56-75$ & Cukup efektif \\
$>75$ & Efektif \\
\hline
\end{tabular}

Dengan menggunakan bantuan SPSS, berikut hasil perhitungan $\mathrm{N}$-gain

Tabel 6. Hasil Perhitungan Uji N-Gain Score

\begin{tabular}{|c|c|}
\hline No & N-Gain Score (\%) \\
\hline 1 & 12.50 \\
\hline 2 & .00 \\
\hline 3 & 66.67 \\
\hline 4 & 42.86 \\
\hline 5 & 66.67 \\
\hline 6 & 16.67 \\
\hline 7 & 20.00 \\
\hline 8 & 33.33 \\
\hline 9 & 25.00 \\
\hline 10 & 16.67 \\
\hline 11 & 37.50 \\
\hline 12 & .00 \\
\hline 13 & 37.50 \\
\hline 14 & 66.67 \\
\hline 15 & 66.67 \\
\hline 16 & 28.57 \\
\hline 17 & 20.00 \\
\hline 18 & 30.00 \\
\hline 19 & 14.29 \\
\hline 20 & 33.33 \\
\hline 21 & 57.14 \\
\hline 22 & 20.00 \\
\hline 23 & 25.00 \\
\hline 24 & 20.00 \\
\hline 25 & 33.33 \\
\hline 26 & 20.00 \\
\hline 27 & 20.00 \\
\hline 28 & 25.00 \\
\hline 29 & 16.67 \\
\hline 30 & 25.00 \\
\hline Rata-rata & 29,90 \\
\hline
\end{tabular}

Berdasarkan hasil output di atas diperoleh nilai rata-rata $\mathrm{N}$-gain Score sebesar 29,90. atau $29,90 \%$ termasuk dalam kategori tidak efektif. Hal ini cukup dimaklumi mengingat tatap muka dilakukan secara virtual melaui video conference dan pembelajaran online pun mengalami banyak kendala, akses internet yang terbatas dimana jaringan internet benar-benar belum merata ke seluruh pelosok negeri, keterbatasan biaya karena tatap muka secara virtual melalui video conference via Zoom atau google meet membutuhkan kouta yang lumayan besar walaupun pemerintah sedikit telah membantu kouta internet gratis bagi pengajar dan mahasiswa, dan lain sebagainya.

Berbagai kendala dan keterbatasan itu menyebabkan pembelajaran belum dapat dilaksanakan secara maksimal, sehingga wajar sekali efektivitas model pembelajaran Blended learning dalam penelitian ini tidak efektif untuk meningkatkan hasil belajar mahasiswa prodi PBI dalam mata kuliah statistik pendidikan.

Hasil penelitian ini juga didukung oleh beberapa literatur yang menyebutkan bahwa pembelajaran yang dilaksanakan secara daring belum memberikan dampak yang signifikan terhadap hasil belajar [5]. Walaupun dengan segala kemudahan yang ada pada pembelajaran daring karena teknologi, namun pembelajaran daring juga masih memiliki kelemahan diantaranya adalah sistem pembelajaran daring mengurangi interaksi sosial antara pendidik dengan peserta didik yang berakibat pada kurangnya kontrol akademik dan sosial oleh pendidik serta berdampak pada terabaikan peserta didik yang memiliki motivasi rendah dalam belajar sehingga mengakibatkan rendahnya hasil belajar [6].

Banyak faktor dan kendala yang membuat perkuliahan atau pembelajaran yang dilakukan secara daring pada masa pandemic covid-19 belum efektif memberikan dampak pada kemampuan akademik mahasiswa. Diperlukan persiapan yang matang dan butuh waktu yang cukup panjang dalam menyiapkan pembelajaran secara daring oleh berbagai pihak untuk memiliki efektivitas yang sangat tinggi dalam meningkatkan pengetahuan peserta didik agar memperoleh hasil belajar yang maksimal dan memuaskan.

\section{Kesimpulan}

Berdasarkan hasil pengujian hipotesis terlihat bahwa Ho ditolak dan $\mathrm{Ha}$ diterima. Sehingga dapat disimpulkan bahwa ada 
perbedaan rata-rata antara hasil belajar Pretest dengan hasil belajar Posttest yang artinya ada pengaruh penggunaan model pembelajaran Blended Learning untuk meningkatkan hasil belajar mahasiswa. Namun berdasarkan uji normalitas gain, diperoleh nilai rata-rata $\mathrm{N}$ gain Score sebesar 29,90. atau 29,90\% dimana nilai ini termasuk dalam kategori tidak efektif. Hal ini cukup dimaklumi mengingat tatap muka dilakukan secara virtual melaui video conference Zoom atau google meet. Berbagai kendala dan keterbatasan yang menyebabkan pembelajaran belum dapat dilaksanakan secara maksimal, sehingga wajar sekali efektivitas model pembelajaran Blended learning dalam penelitian ini tidak efektif untuk meningkatkan hasil belajar mahasiswa prodi PBI dalam mata kuliah statistik pendidikan.

\section{Daftar Pustaka}

[1] Wekke, I. S., \& Hamid, S. (2013). Technology on Language Teaching and Learning: A Research on Indonesian Pesantren. Procedia Social and Behavioral Sciences, 83, 585- 589.

[2] Sari, M. (2012). Blended Learning, Model Pembelajaran Abad ke-21 di Perguruan Tinggi. Ta'dib, 17(2). 126-136.

[3] Bonk, C. J., \& Graham, C. R. (Ed.). (2006). The handbook of blended learning: Global perspectives, local designs (1st ed). Pfeiffer.

[4] Sugiyono . (2014). Statistika Untuk Penelitian. Bandung : Alfabeta.

[5] Astuti, C.C.,Sari, H.M.K., \& Azizah, N.L (2019). Perbandingan Efektifitas Proses Pembelajaran Menggunakan Metode E-learning dan Konvensional, Proceeding of the ICECRS, 2(1), 3540

[6] Hartono, S. (2017). Apa Saja Kelebihan dan Kelemaha Penggunaan E-Learning. Binus School of Information System.

[7] Raharjo,S. (2019). Cara Menghitung $\mathrm{N}$-Gain Score Kelas Eksperimen dan Kontrol dengan SPSS. SPSS Indonesia.
[8]

Abdullah ,W. (2018). Model Blended Learning dalam Meningkatkan Efektivitas Pembelajaran. Fikrotuna 7(1) 855-866.

[9] Hamalik, Oemar. Kurikulum dan Pembelajaran. Jakarta: Bumi Aksara, 2012.

[10] Humasah (2013). Pembelajaran Bauran (Blended Learning). Prestasi Pustaka Publisher.

[11] Tabah ,Heri \& Aden .(2020). Efektivitas Penerapan Blended Learning dalam Upaya Meningkatkan Kemampuan Akademik Mahasiswa melalui Jejaring Schoology di masa Pandemi Covid-19. Jurnal Pembelajaran Matematika Inovatif. Volume 3 No.5. 